\title{
Egyptian Facebook satire: A post-Spring carnivalesque
}

\author{
Yomna Elsayed \\ University of Southern California, USA \\ yelsayed@usc.edu
}

\begin{abstract}
The Arab Spring offered Egyptians a brief opportunity for political freedom of expression; it also offered many creative youths a chance to experiment with their newfound digital talents. However, this was soon followed by a state crackdown on public forms of dissent; subsequently, creative expression had to find other platforms and modalities to continue its practices of playful dissent. Through Mikhail Bakhtin's (1984) theory of Carnivalesque, this paper examines how Egyptian youths managed to create alternate spaces, other than the highly scrutinised political square, to challenge officialdom and generate their own folk culture through laughter and creative digital arts. This research is based on interviews conducted with administrators and fans of Facebook pages that offer satirical content in the form of memes and remix videos. Fans of these pages mostly belong to the 1980s and 1990s generations, but they also include younger adults whose formative years were those of the Arab Spring. This study argues that, like Bakhtin's carnival, laughter and everyday comedy was a means by which creative artists could continue to express their opinions and indirect dissent amid intensifying state surveillance. These spaces, therefore, constituted third spaces away from polarised politics, where fans could playfully discuss the comedy away from the heat of events. They were spaces where youths could exercise control over the objects of laughter and challenge established institutions. Like the carnival, youths exercised Carnival practices of both reversal and renewal to craft a new folk culture of their own that did not have to abide by the rules of patronising politics.
\end{abstract}

Keywords: Arab Spring, carnival, Egypt, Facebook, politics

\section{Introduction}

The Arab Spring uprisings in Egypt were characterised not only by the sheer number of protesters that flooded the squares (notably Tahrir Square), but also by the playful side they unveiled of Egyptian youth. ${ }^{1}$ Playful politics took many forms depending on the structure of political opportunities: from overt protest signs mocking political leadership in public squares

\footnotetext{
${ }^{1}$ The term youth is loosely used by Egyptians to refer to young adults from 18 to 35 years of age. In this article, I am using the same category to refer to Egyptian young adults.
} 
in 2011, through TV mockumentary shows and online comedy videos in 2012-2013 (Elsayed 2016), to covert online humour disguised in various forms of popular culture after 2013. In the post-Arab spring climate of state repression and ideological polarisation, humour was necessary for youths to build alliances and pass critique, while remaining safe within its ambiguous interpretations and entertaining quality. Following a ban on public, even digital, forms of dissent in 2013 (Protest and Freedom 2017), humour took on more creative and less direct forms.

Spaces for online humour functioned as second-life spaces for the reversal of existing power structures and for questioning and renewing their inherited and outdated pre-set identity markers. Utilising memes and remix videos, Egyptian youth created new forms of folk culture where laughter was celebrated, and experimentation was encouraged along with a shared tolerance for crudeness and coarseness. Like Bakhtin's carnival, these spaces acted as sites of reversal, whereby humour granted them a temporary upper hand over authority figures who became the butts of their jokes. They also acted as sites of renewal, a process of growth and becoming, where in coming up with jokes, they had to analyse media messages, reflect on their experiences and create thoughtful covert critiques that neither alienate nor subject them to state retaliation. In analysing political humour in authoritarian settings, this study adopts a wider understanding of politics as the domain in which meanings and power relations are contested and negotiated (Jackson 1991). This research draws from interviews conducted in 2018 with twenty participants who were either creative administrators or fans of satirical Facebook pages. Through textual analysis of interviews and the creative digital art created and posted on these pages, it explores political digital humour in post Arab Spring Egypt, the forms it takes and the purposes it serves in advancing agendas for political and social change. It does so, while examining the economic, political and social contingencies when this humour crosses the invisible moving line between culture and politics.

\section{Background}

Following the 2011 uprising, ${ }^{2}$ public forms of dissent have been progressively outlawed, and Egypt underwent a tumultuous transition that saw a military interim period, the first democratic election in its modern history, and the ousting of President Mohammed Morsi. ${ }^{3}$ During this time, the temporary break in freedom of expression accorded by the Arab Spring uprising gradually shrank (Abdulla 2014). Immediately following the uprisings, surgeon-turned-comedian Bassem Youssef pioneered online comedy videos using remix videos; in these videos, he repurposed famous movie scenes to offer commentary on contemporary political events. Soon, many Egyptian youths followed suit in offering satirical political commentary, such as Talk Shoes, JoeTube, Attwa Kenana, and Bakoos TV (Elsayed 2016). Some of these comedians, such as Bassem Youssef, even became mainstream and widely popular around the Arab World. The comedy in these shows was direct and openly critical of the military and government at the time. While the Arab Spring brought a lot of political and generational schisms - previously masked by blanket oppression in the Mubarak regime - to the fore, the heightened state surveillance and the vilification that followed 2013, resulted in even sharper polarisation over the role of the military in political life. In 2014, Bassem Youssef, had to put an end to his popular show, $A l$ Bernameg, after his show faced a slew of lawsuits for criticising the military leadership. He was cited saying "I'm tired of struggling, of fearing and worrying about my safety and that of my family" and that "the present climate in Egypt is not suitable for a political satire programme"

\footnotetext{
${ }^{2}$ In 2011, Egyptian president Hosni Mubarak was removed from power following popular protests against his 30-year military backed dictatorship.

3 Mohammed Morsi was the first democratically elected president following the 2011 uprisings. He was ousted by the Egyptian military in July 2013.
} 
(Gupta 2014). Some shows such as Talk Shoes stopped all together, while others, such as JoeTube moved with their producers to neighbouring countries.

With political criticism highly scrutinised, satire started to take on new targets and modalities. Playful criticism, for example, moved on to the less perilous, yet more pervasive, cultural and parental authority. Political criticism, nevertheless, continued in much more covert ways. Satire started to take on less verbal and more visual and artistic forms that utilised memes and remix videos. As Laineste (2016) suggests, humour continually reinvents the text by deconstructing and reconstructing the text. Memes and remix videos worked to reconstruct the original, possibly state-approved, text by adding "new layers of meaning and context" (Laineste 2016: 7).

A meme is an image that consists of "a picture and a witty message or a catchphrase" (Grundlingh 2018: 9). They are "idea complexes" that enable us to express multifaceted ideas through a simple phrase or image (Shifman 2014: 173). Popular culture scenes are a rich source for meme creators. Alongside the direct written message that usually accompanies the meme, the scene by itself tacitly carries the collective meaning it acquired throughout the years. Like movie scenes repurposed as memes, "all political remix videos are made without the permission of the copyright holder and rely on the fair use doctrine" (Jenkins 2010: para. 4). They are a mix of cut frames from the original scene juxtaposed with audio or visuals from the present reality, or simply a succession of cut frames playfully connected to provide an alternate message other than the one originally intended such as an indirect commentary on real events by the characters in the scene. These techniques were widely utilised by Egyptian youths on social media websites such as Facebook and Twitter.

Notably, following the 2011 uprisings, the Egyptian Facebook scene has seen a sudden rise in the number of satirical Facebook pages that overwhelmingly rely on memes and remix videos to provide political and cultural commentary. Some of these pages have millions of followers. Reliance on such indirect messaging serves to both subvert the political authority and its symbols as well as protect its artist creators. Additionally, by existing in the realm of entertainment and satire in specific, such products help advance ideas of social change, without disturbing strongly held political views (Elsayed 2016). However, despite the tacit nature of most of these pages, a direct mention of political authority figures was still risky for many of these creative artists (President Smiley 2016; Egyptian Satirical 2016). Nevertheless, the repercussions for online criticism were less severe and systemic than those incurred by the open practice of politics, especially when it gradually started to employ more clandestine techniques.

\section{Egyptian political humour in the $20^{\text {th }}$ century}

Egyptian humour is not a new phenomenon; some even date it back to the pharaohs (Houlihan 2001; Attardo \& Ergül 2014). In modern times and prior to the 1952 revolution, Egyptians have used humour to pass political critique against the British occupation and Egyptian politicians (El-Menawy 2017). Sometimes, it took the form of satirical ballads, otherwise known as Zajal. Artists and journalists such as Bayram Al Tounsi, Abdullah Al Nadim and Yaqub Sanu pioneered this art. Al Nadim was also known for his satirical magazine Al Tankeet wa Al Tabkeet (“Joking and Reproach") (Helmy \& Frerichs 2013). Through pointed criticism, his satirical articles poked fun at authority figures and their policies. According to author Ahmed Bahaa Al Deen, "Al Nadeem used the joking style close to the heart of Egyptians to lead to their eventual reproach and awakening" (Quoted in Radwan, 2017, para. 14). El Ba'kouka (meaning an object with a malleable shape) was also a satirical paper infused with political humour (Helmy \& Frerichs 2013). Freedom of expression, however, was severely restricted by the Nasser, Sadat 
and Mubarak regimes respectively (i.e. regimes that came out of the 1952 revolution which ousted King Farouk and ended the British occupation of Egypt) (Abdulla 2014).

Comedy transformed from the realm of the political, which was heavily monitored, to the realm of cultural and social critiques. The 1970s and early 1980s saw the debut of two widely famous plays that took aim at the elderly and parental authority (in contrast with Egyptian culture traditional emphasis on respect for the elderly) (Elsayed 2016). The two plays were Madraset El Moshaghbeen ("The school of the mischievous") and El Eyal Kebret ("The kids have grown"). Despite steering away from political criticism, the debut of the two widely popular plays still received backlash, where criticising the elderly bordered on criticising political authority, who were most often than not elderly as well. Many credited those two plays for having a "bad influence on future generations" (Khalaf 2012). Hence, this familiar accusation of disrespect was often wielded as a weapon to silence protests in 2011 and later satire in 2012-2013.

The 1980s and 1990s have seen a surge in critical comedy that sometimes bordered on political criticism. Playwright Lenin Al Ramly wrote and directed several iconic plays for the famous theatre actor Mohammed Sobhy. They were distinguished by their symbolism and multilayered meanings. Kandeel (2016), an Egyptian cartoonist and vlogger in his 30s, attributed the fame of Mohammed Sobhy to Lenin Al Ramly's direction and writing. Sobhy's authoritarian and less creative character, he added, showed in his later plays (that were not directed by Al Ramly). Mohammed Sobhy was also a famous film and TV actor. His 1994 sequel, Yawmeyat Wanees ("Wanees Diaries") and A'elat Wanees ("Wanees family") were widely popular among the 1980s and 1990s generation. Through a situational comedy, it featured a mother and father determined on raising their kids righteously amid what they viewed as society's declining moral standards; Sobhy's paternalistic comedy, however, was clearly a departure from Lenin's more layered and complex flavour of comedy.

Following the 2011 uprisings, comedy receded from mainstream TV to online amateur shows. The audience was moving online, and so were amateur talented youth. Egyptian youths were not isolated from the global shift towards digital platforms (Twenge et al. 2019). It is estimated that there are 35 million Facebook users in Egypt (Internet Users 2019), 29 million of which are millennials (Social Media 2018). Additionally, Egyptian youth who took part in the 2011 protests were often vilified, and their brand of critical comedy was often censored by mainstream media (Woodsome \& Elshinnawi 2012). Hence, TV comedy regressed to slapstick comedy and were practically devoid of critique. Bassem Youssef's earliest online show, $B+$, arguably set in motion a wave of online political comedy that later transformed to cultural and social critiques using the more indirect and less outspoken tools of memes and remix videos.

While my participants sometimes referred to their work as "sarcasm," this may not be the accurate translation of what they actually produce which tends to fall more generally into satire, defined as "a form of comedic criticism... [whose] aim is not cruelty but rather to point out faults in government, society, individuals or the human condition" (Singh 2012: 70). Irony and sarcasm were two verbal forms of satire (Singh 2012) that were interchangeably utilised by these productions. Egyptian youths' satire, however, took on many other modalities, such as visual and performative arts. Humour and satire are used interchangeably throughout this study to reflect the range of comedic styles utilised by youth; while sometimes the comedy was satirical and infused with socio-political critique, most of the times it was humorous with the intent of entertaining (producing amusement) and establishing participatory practices. 


\section{An online carnivalesque}

In writing about Rabelais, Bakhtin (1984) noted that to understand the humour in The Life of Gargantua and Pantagruel, one has to understand the context in which they were written. Rabelais wrote his pentalogy at a time of heightened religious and political persecution in $16^{\text {th }}$ century France. The stories of the two giants Gargantua and Pantagruel celebrated the triumph of folk culture over officialdom. They reflected the spirit of folk culture, particularly the carnival where hierarchies were reversed, and folk heroes were celebrated as the ones capable of laughing off the seriousness of the church and feudal kings. They were written at a time when the spirit of the carnival was slowly eroding from the public space, as societies were slowly moving from feudal to modern societies at the beginning of the renaissance. Bakhtin (1984), however, suggested that this spirit persisted through literary forms, which he termed carnivalesque. Carnivalesque is a literary style that continues the tradition of subverting authority through humour and grotesque realism. Rabelais' writings captured the essence of the carnivalesque in their utilisation of crude and grotesque humour. The role of the grotesque, argued Bakhtin (1984: 48), was to suggest "the potentiality of an entirely different world" by challenging the stable and sometimes "false" unity of officialdom.

Rabelais' philosophy of laughter was inspired by Aristotle's famous formula "of all living creatures only man is endowed with laughter" (Bakhtin 1984: 68). At the time of the Renaissance, laughter was seen as a human privilege that distinguished man from other creatures. The introductory poem to Gargantua summed up the Renaissance philosophy of laughter: "Better to write about laughter than tears. For laughter is inherent to man" (Quoted in Bakhtin 1984: 68). This philosophy, argued Bakhtin (1984: 12), underscored the positive traits of laughter. Carnival laughter "is ambivalent: it is gay, triumphant, and at the same time mocking, deriding. It asserts and denies, it buries and revives... it is also directed at those who laugh." Unlike modern day satire, which places the satirist above the object of ridicule, people's festive laughter did not exclude them from the wholeness of the world they were laughing at (Bakhtin 1984).

The carnival constituted a "second life" for regular people, where they could be free of the constraints of class and the feudal political structure, even for a temporary period (Bakhtin 1984). Bakhtin (1984: 6) suggested that carnivals more than any form of celebration "offered a completely different, nonofficial, extra ecclesiastical and extra political aspect of the world, of man and of human relations; they built a second world and a second life outside officialdom." An essential element of this second life was the "reversal" of hierarchies in which "ephemeral kings" and queens were elected for a day, clothes were worn inside out, while heads were crowned in trousers, to emphasise the relativity of hierarchy as opposed to the stable, immovable world of the church (Bakhtin 1984). Reversal in carnivals was thus a departure from the principles of stability that governed the official culture to the openness of possibilities (Elliot 1999). The seriousness of the church is what necessitated the carnival as a vent for laughter which was described by Bakhtin as "the second nature of man" (Bakhtin 1984: 75).

At the heart of grotesque humour characterising the carnival world, is the theme of renewal, and change. The carnival was a celebration of the grotesque with its images of birth, death, and sexual intercourse. The grotesque body was not one separated from the world, but one open to it through those bodily actions. Hence, the grotesque body symbolised the human potential for growth beyond its limits. Politically, the pictures of change and renewal emphasised a sense of "gay relativity of prevailing truths and authorities" (Bakhtin 1984: 11).

The face of officialdom in Egypt was similar in many ways to that of $16^{\text {th }}$ century France, in its political and cultural censure. While the legal consequences for political criticism were far more severe than those of religious criticism, there were social sanctions associated with the criticism of state-sponsored religious or idolised figures. Conversely, Islamic interpretations that 
emphasised Islam's concern with social justice were muted or vilified as promoting terrorism. State control pervaded all forms of official culture, from religious Friday sermons to TV series and talk shows. The Egyptian regime has recently introduced more controls that dictate the themes and scripts of the most popular shows as a condition for continuation on the air (Walsh 2019). Hence, the humorous covert critiques of the political, religious and cultural authorities on Egyptian satirical Facebook pages constituted a welcome break from officialdom in many ways. They reflected many of the elements of the carnivalesque as a space for positive laughter, and a second life outside officialdom. In these spaces, reversal and renewal were practiced daily, working slowly to erode old structures while establishing a new folk culture. In the authoritarian context of post-Arab Spring Egypt, I ask the following research questions: What does the study of carnival laughter tell us about the role of Facebook satirical pages in Egyptian society? Are they merely a pressure valve in an increasingly repressive context, or are they part of an aspiring cultural movement, that unlike its political predecessor, can slowly work to erode the structures and legitimacy of official authority?

\section{Methods}

Facebook stands as the most widely used social media platform in Egypt (74.67\% of Egyptian social media users), with some satirical Facebook pages, comprising almost $40 \%$ of Egyptian Facebook users (Fastest-Growing Pages 2019; Social media stats Egypt 2019). Given the wide popularity of Facebook and the opportunities it offers Egyptian youths' for expressing dissent, I investigate the negotiations and digital practices of Egyptian youth on some of the most wellknown satirical Facebook pages in Egypt.

I used a combination of online interviews, and participant observation to gather the data for this study. I interviewed the administrators of the most popular satirical Facebook pages and their fan participants between 2017 and 2018. The Facebook pages targeted with this analysis, though different in their scope or niche, all used satire and popular culture in memes and remix videos to pass social or political critique of youths' lived realities. Some pages had a single admin, others were run by a group of creative admins. To protect the identities of these pages' administrators, I will use pseudonyms to refer to them. The following is a description of their content:

A1: a very popular Egyptian satirical Facebook page with millions of followers. It utilizes a range of memes and video remixes to criticize political and traditional authorities and also to comment on matters of public opinion.

A2: a popular satirical Facebook page with over a million followers that creates satirical remixes of past local (mainly state-produced) and global cultural productions.

A3: a creative Facebook page that relies on users' dubs of famous songs and TV scenes in addition to critical memes and remixes.

A4: a single-admin satirical Facebook page that gained wide popularity due to its creative memes and commentary on the Egyptian cultural scene.

A5: a single-admin Facebook page run by a creative artist and musician to provide satirical commentary on the Egyptian cultural scene.

A6: a single-admin Facebook page run a by a university graduate providing funny videos on the state of Egyptian education.

A7: A single-admin satirical Facebook page run by a female vlogger criticizing the gender and cultural norms perpetuated in TV advertisements from a feminist perspective.

A8: A single-admin Facebook page run by a female vlogger discussing prevalent cultural norms and perspectives from her international travel experience in a comedic way. 
A9: a group-run Facebook page that prides itself on offering critiques of what it describes as "Egyptian low art," of past state-produced TV shows and movies.

A10: A group-run satirical Facebook page that provides satirical commentary on Egyptian Engineering schools as they relate to Egyptian culture.

A11: a group-run Facebook page that provide generational, partly nostalgic, humor on the Egyptian eighties' generation.

A12: A group-run satirical Facebook page that provide satirical commentary on overly dramatic scenes in state-TV productions.

A13, A14: Two satirical Facebook pages that utilize Egyptian actor Mohammed Sobhy's moralistic stance as a launch pad for their critiques on state-sponsored Egyptian comedians.

I recruited creative producers and their fan participants utilising a combination of purposive and snowball sampling as well as through informal creative or fannish networks. I interviewed twelve popular creative content producers (with followers ranging from 200,000 to 14 million), and eight of their fans: a total of twenty in-depth interviews lasting from 1 to 2 hours each. All participants were between the ages of 18-37. Their occupations ranged from university students to working professionals in the fields of marketing, business, entertainment and engineering.

Page administrators were reached via their pages' instant messaging feature. Fan participants were chosen based on their active following of one or more of these pages and their preference for online satirical content. Active engagement was defined as regular sharing of content from these pages. Interviews were structured differently depending on whether the participant was a content/producer or fan, with the earlier focusing on the creative process and motivation for creativity, and the later focusing on the experience and effect of such content on fans. Interviews were mostly conducted on Facebook messenger or Skype. They were conducted and transcribed in Arabic, and then translated to English.

Interview transcripts were thematically analysed using Braun \& Clark (2006) method of thematic analysis. Concepts from literature informed the coding and identification of themes (Braun \& Clarke 2006). Though primarily informed by the literature, the coding was also reflexive to allow for the introduction of new themes (Saldana 2009). In the first cycle of coding, I identified statements pertaining to the concept of carnivalesque as units of analysis. The statements were then coded using process coding in which they were assigned codes based on the function/effect of these pages (Saldana 2009). In the second cycle of coding, data was analysed to come up with new themes that relate to the far-reaching effects of this carnivalesque culture. The guiding principle in theme identification was not necessarily dependent on "quantifiable measures - but in terms of whether it captures something important in relation to the overall research question" (Braun \& Clarke 2006: 10).

Creative participants were encouraged to share examples from their work. Together with my own observational data, this provided sufficient material for my textual analysis of the memes and remix videos. I selected memes and remixes from 2016 to 2018 that corresponded with instances of public outrage or that appeared to defy official cultural or political traditions. I conducted a textual and visual analysis of these memes and remixes guided by the same principles of Bakhtin's carnivalesque (Frey et al. 1999). Results from both the thematic and textual analyses were triangulated to develop a more comprehensive understanding of the phenomenon (Bauer \& Gaskell 2000). While both analyses relied on the same themes, they illuminated different aspects surrounding the creation, circulation and effect of such memes.

I identified five main themes that capture the characteristics and effects of these pages on youths' understanding of themselves as citizens and agents of change. Satirical Facebook pages functioned as spaces for showcasing the productive capacity of laughter, for providing an alternative space (cf. second life) outside the bounds of officialdom, for the reversal of social and political hierarchies, the renewal of social meanings, and for the creation of a new identity 
based in play. In these Facebook satirical pages youth exercised their carnivalesque practices to craft a new youth/folk culture of their own away from the closed off spaces of traditional polarising politics.

\section{Positive laughter}

The effects of subversive comedy have been studied by many in Western democracies (e.g. Cao $\&$ Brewer 2008). However, few have examined their effects in authoritarian contexts (Astapova 2015 ; 2017), primarily due to the scarcity of such productions in the mainstream, but not folk, culture and the state censorship of any outward political content, even if it was comedic. The Arab Spring uprisings, however, provided a temporary break from the iron grip of the state on cultural productions. Despite Egypt's return to more authoritarianism, we continue to see the effect of the Arab Spring in new forms of disguised dissent through satirical Facebook pages. There is almost a demand for comedy due to mounting state control and increased polarisation between those who support the military state and those who do not (Elsayed 2016). Reem, ${ }^{4}$ a 37-year-old female fan participant, noted: "Comedy is better in delivering the message, it puts people in a receptive mode, not on the edge, even if their views were opposed." This quality of disarmament in humour was essential at a time when vilification was happening on all political sides.

Specifically, with the widespread disenchantment in traditional politics and parties following the military takeover in 2013, many youths found it difficult to keep up with news updates, which were themselves becoming more ludicrous. Hence, comedy was the creative producers' way of luring youths back into the public space without the emotional toll associated with serious news consumption. Yara, a 37-year old female fan participant, indicated that she used to wait for the Thursday News (a weekly post recapping Egypt's news in satirical commentary) as it was her only palatable way for consuming news at a time when "everything was pushing [them] towards sadness." She noted that she would not have paid attention to the news if it were not for the comedy, where "the degree of despair made it into comedy." Nadia, an 18-year-old female fan participant, shared a similar function of humour, suggesting that it made her aware of issues she would have otherwise ignored. She frustratingly noted, "we are fed up with solving problems by talking... talking... talking, comedy is better as it can let me know something I would not have otherwise cared about or paid attention to if the post were serious." Stark (2003) suggested a similar effect in his media literacy classes, where humour helped students pay more attention, recall more examples, and extend their period of recall to following semesters.

Youth were inundated with official culture that they were almost desensitised to its messages. Like the carnival, they viewed comedy as both an escape and a space of potentiality. To Khaled, a 32-year-old male vlogger and popular remix artist on Facebook, comedy was "a way to create influence, unlike serious content which had no effect." It was also a means for gradual subversion, as Ashraf, administrator of one of the pages asserted:

Following 2013, we started making comics about authority figures, people started to think you should not make fun of them. That they were above criticism. So, we made it into doses, and we increased it bit by bit. We used our tools to convince them that there is no one above criticism. We took it step by step until, as you can see, [authority figures] have turned into clowns that everyone criticises. This is where my role ends, I have achieved what I wanted.

\footnotetext{
${ }^{4}$ All participant names are fictitious.
} 
The theme of breaking sanctity was shared by many of the pages and were not only restricted to the political, but rather expanded to include the religious and the cultural. Ahmed, a 33-year-old male administrator of a page that critiques past popular cultural productions, noted how even criticising iconic actors, turned into a taboo. He therefore took it upon his page to point out the banality in some of their productions, which, he noted, was met by fierce opposition from some of their fans to the point that "people started inserting meanings that did not exist in the movie or at least were not developed enough to increase the value of the production and justify their adoration." In their page, they worked to challenge this uncritical way of consuming popular culture. Fan participant Reem, noted a similar effect for satirical Facebook pages:

They made us talk about central issues that used to be taboos, such as marital relations, sexual harassment, politics of course, as well as religion. There was self-criticism for the first time. All governments autocratic or democratic now fear this third power, people's voices are amplified. In Egypt, they control all media, but they cannot control us online. Even if they [were to make] an alternative Facebook, they would not make an alternative twitter or YouTube.

In addition to grabbing attention and breaking sanctity, laughter can be one effective way for exerting control over our immediate environments by developing our ability to laugh at political and social situations (Levine 1978). In 2017, following terrorist bombings of two Coptic churches on Palm Sunday, a wave of outrage swept through Egyptian social media condemning the attacks. Social media administrators and followers of satirical Facebook pages, circulated messages of mourning and anger against terrorism and criticised the state security' focus on protecting the regime more than the people. However, following the announcement of a new emergency law in response to the bombings, these same pages, were soon ablaze with satirical memes about the new restrictive law. The new law allowed state security to search phones in traffic stops or in police patrols. Youths collectively and spontaneously made fun of the fact that they were already undergoing emergency rule, and they wondered in memes at the "very dangerous" content that could be on their phones if they were stopped and searched. One of these memes (Figure 1) depicted a movie scene of a police officer inspecting a selection of peoples' phones. Some phones had pictures of actress Scarlett Johansen, others had messages of love, or heart break. The officer's imagined reactions were also revealing of who is viewed by the state as a "good," yet harmless, citizen. In these memes, the officer let go those with celebrity or nude pictures (Figure 1, left) and sent the diligent engineering student to the police car for further investigation (Figure 1, right), alluding to the state's targeting of not only activists, but those who are most educated or politically aware. ${ }^{5}$

\footnotetext{
${ }^{5}$ Engineering public universities admit students with highest scores in Thannweya Amma's standardised tests (General Secondary Education).
} 


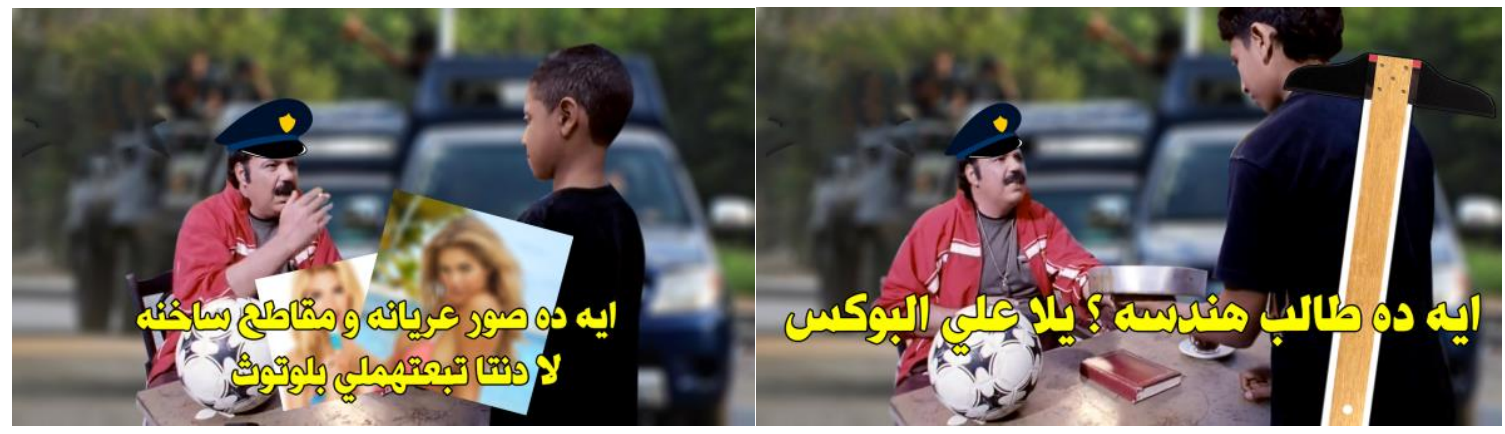

Figure 1. (Left) Officer: What's that, nude pictures and XXX video clips, send them to me over Bluetooth (Right) Officer: What's that? An engineering student? Go to the police car (Image source: A1).

Sara, a 33-yearl-old female fan participant, described political comedy as youths' way for retaliating against oppression, because there were no other venues for doing so. Yara expressed a similar sentiment and suggested that satire worked as the least one can do when faced with a depressing political outlook: "at least I could laugh at it," she concluded. Like carnivals, Satirical Facebook pages managed to turn laughter into a political statement, at times providing comic relief from the oppressive reality, possibly a release of repressed nervous energy (Freud 1963) and at others a way for critiquing these political and social realities.

\section{Second life}

Carnivals were distinguished by their ability to exist outside the spaces of officialdom, offering what Bakhtin (1984: 6) described as "an extra ecclesiastical and extra political aspect of the world." Hence, the rules and regulations that governed the outside world were suspended, if not reversed. Kamel, 35-year-old male digital artist noted,

My page is a space where I share with everyone: an unusual space free of rules where anyone can say whatever they want, or whose rules are bizarre such as shooting a video at night despite the name of the show being the "morning segment."

Ambivalent laughter was the language of the carnival (Bakhtin 1984). The language on these pages is no different. It consists of the collective punch lines of popular culture scenes converted into memes and material for remix videos. Each of these punch lines carries layers of meaning shared only by this generation of youth. The meaning of each meme was not only its originally assigned mainstream meaning, but an amalgamation of the various connotations it acquired through its usage in different contexts and events. Ahmed, a digital cultural critic, added:

Social media became the archive and the first place where you could follow and watch the memorable scenes in movies and their scripts, so people started to cut those scenes and juxtapose them on their lived realities. This turned our reality into irony, even if the original scene was serious.

However, the comedy was funniest, noted digital artist Kamel, when created through a "contrast or fusion between incompatible things." As the incongruity theory suggests, humour stems from the violation of people's mental patterns or expectations, thereby creating an element of surprise and amusement (Morreall 2014). This juxtaposition worked to create an impossible world, wherein international artists are imagined as part of the local culture and its practices. Kamel explained: 
When you see Abdel Basset Hamouda [Egyptian Sha'abi ${ }^{6}$ singer] and Adele together, they are very incompatible, and it's impossible that they get together, it's the land of nowhere. I made an album... where I had Leonardo DiCaprio \& Kate Winslet dressed as Egyptian peasants and working in the fields, reimagining the Egyptian villages. In this world, Adele bakes, and feeds the ducks, while Scarlet Johansson carries a water jug. This made 45,000 shares, because it is impossible that this could happen. Do the impossible and people will love it.

This second life was the place where creative digital artists felt most at home. Despite the fact that most of the producers I have met have been recruited by mainstream comedy shows as scriptwriters, they referred to their pages as their main occupation. Gamal, a 35-year-old male vlogger and creative digital artist asserted: "I worked with Ahmed Amin [mainstream comedian who also debuted online], who is mainstream, but I love life underground; I like new media and I believe the future is digital, where there is a direct way to deliver your message."

With most public spaces of expression shut down, satirical Facebook pages worked as an alternative space whereby gatherings, albeit virtual, were still allowed, and imagination reigned. This affirmed to fans and artists alike that they could still dream despite the hiatus of real possibilities.

\section{Reversal}

Carnivals constituted a second life primarily through the mechanisms of reversal and renewal. Reversals were sometimes political, but most of the time they were cultural due to political censorship. Youths therefore resorted to clandestine means for expressing their subversions, at times directly targeting political figures (e.g. at moments of public outrage), and at others targeting the cultural apparatus of that authority represented by state-approved celebrity figures. Juxtaposing the image of the leader over a character that was being ridiculed or experiencing an embarrassing situation sufficed to subvert the leader by putting him in an unflattering light without explicitly criticising him. In a movie scene, the face of the military leader is photoshopped over the face of a character that is being called "Loser... Loser." This method also served as a layer of protection from the prying state.

Reversals were also cultural. Creative artists leveraged their digital photo-shopping skills to reimagine Adele as Adeela (a working class Arabic name) and the song "Rolling in the Deep" as Marmagha fel Ghaweet [colloquial for "paddling in the deep waters"]. Kamel related: "I have an album that is all Photoshop: I made foreigners drink sugar cane juice "which never happens" or sell a kind of Egyptian fruit (thorny figs, sold on the streets)." To Kamel, these albums (Figure 2) were created to make people laugh, and to assert his technical ability at photoshopping, but they also served as a reimagining of his restricted reality, low on international exposure, and abundant with national state-approved ones. This juxtaposition of world-renowned artists in the Egyptian local scene, a form of glocalisation (Zidani 2016), helped young Egyptian youth exercise control over things they did not have much control of, such as travelling abroad or encountering their much-idolised Western celebrity figures. However, unlike the top-down flow of Western media, they were able to reimagine these encounters, but on their own terms, using unlikely, but familiar, contexts and clothing to bring those idols down to their "land of nowhere" where everything is possible.

\footnotetext{
${ }^{6}$ Popular working-class Egyptian music.
} 


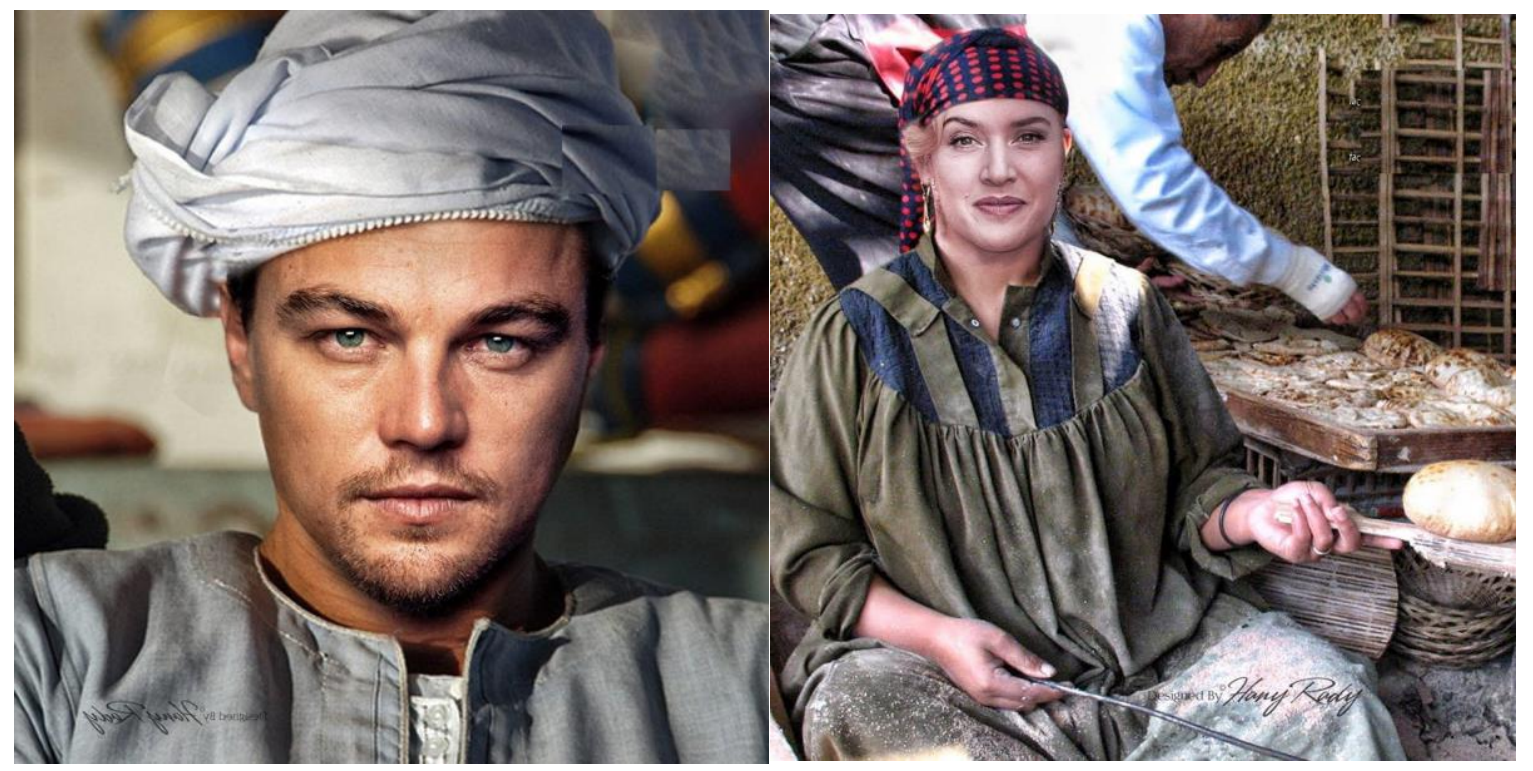

Figure 2. Actors Leonardo DiCaprio and Kate Winslet reminaged as Egyptian peasants (Image Source: A2)

Sometimes reversals worked to highlight a discrepancy in public attitudes. Mohammed Sobhy, a stage actor and one of youths' childhood idols, was widely yet playfully criticised for his overly moralistic rhetoric. In 2013, Sobhy famously suggested that Egypt is facing a crisis in morality ("Egypt is suffering" 2013). Kamel was one of the satirical artists who set the trend of mocking Sobhy's moralism. He recounted: "he [i.e. Sobhy] seemed to be trading with ethics, speaking like a preacher. This led people to contrast his call for ethics with some of his earlier movie scenes that contradicted this so-called morality." Youth playfully alluded to Sobhy's overuse of the word "morality" by creating memes that placed ethics in the course of their everyday lives, such as depicting him as the Morality Police (Figure 3), or juxtaposing his pictures with funny memes about finding morality in unlikely places. Some of these memes read: "Do you take morality in the vein or muscle?", "I opened the fridge and found Molokheya [i.e. popular Egyptian dish] with morality," or "Mmmm... custard with Morality," as if those meals would taste better with morality (Figure 4). At the heart of this criticism is youths' rejection of Sobhy's reductionist view, expressed in mainstream talk shows, where Sobhy, a state supporter himself, attributed most of the problems in Egyptian society to a crisis in morality while disregarding structural and political impediments. Hence, it was no surprise that the once 
idolised figure of Sobhy, was now being ridiculed in memes that imagined him finding morality in daily meals or medications.

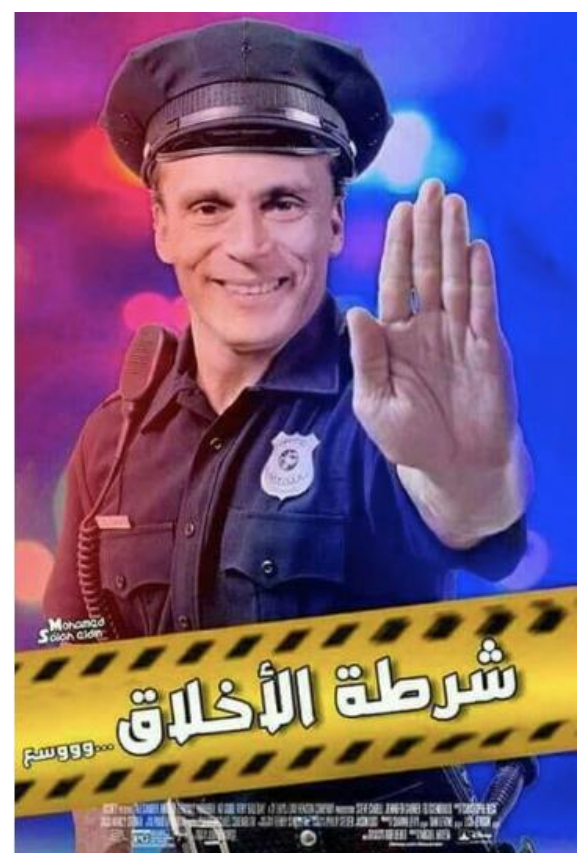

Figure 3. Mohammed Sobhy depicted as a Morality Police in a satirical meme (Image Source: A13)

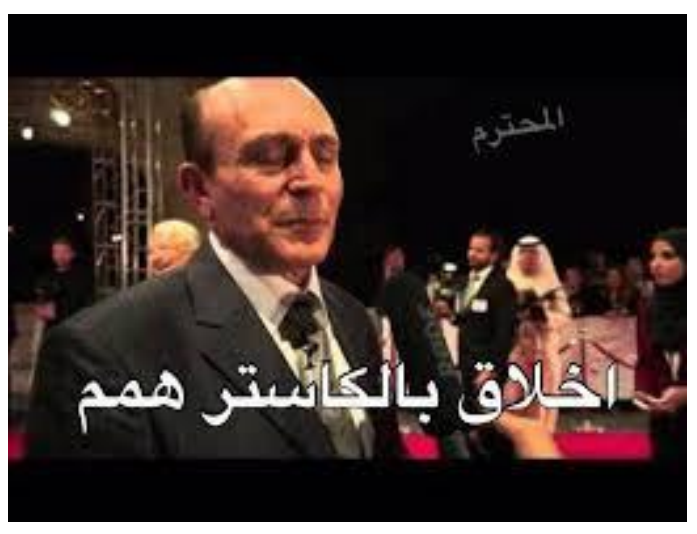

Figure 4. Mohammed Sobhy depicted saying "Custard with Morality... mmm” (Image Source: A14)

In the upside-down world of these pages, official sanctities and hierarchies are no longer applicable, and hence previously venerated figures are ridiculed, or photoshopped in ways that reflect youths' true opinions of them.

\section{Renewal}

A casual follower of the satirical Facebook pages might feel overwhelmed by the sheer number of memes, videos and comments shared daily. Sometimes, a political satirical meme is buried between ten other non-political memes about summer heat, relationships or the exam season. Irrespective of whether it is intentional or not, this ephemerality protected the administrators and fans of these pages from the casual surveillance of state and parents. Overt political criticism 
was highly scrutinised by the state that surveilled social media posts on a regular basis. Therefore, satirists had to continually update and renew their methods of creative subversion. Sometimes subversions were even more hidden and only funny through the context in which they were shared. Hence, non-regular followers would miss out on the humour, which served as an extra layer of protection from social and political scrutiny. For example, following the announcement of the new state of emergency in 2017 (ostensibly to fight terrorism, but essentially to limit protests), people started sharing pictures of leader "support," yet to express their dissent. To an outside observer, they were showing support, but to a close follower, these images clearly contrasted with their previous playful subversions and were hence a source of laughter.

However, ephemerality is also a by-product of the dynamic nature of these pages and their creators, who comment daily on global and local popular culture and (occasionally) politics. The memes sometimes grow into trends, when all satirical pages comment on the same news or pick up the same flop in a popular culture production. Followers as well join these trends by creating their own memes and sending them to the pages that would subsequently add them to their stream of satirical memes that would eventually reside in albums of their collective creations.

Social media trends are therefore dynamic and constantly changing, allowing participants to take part in conversations around events using different modalities. The audio-visual modality specifically allows youth to join the conversation using their own brand of creativity. The youths grapple with their increasingly restrictive political reality using trends of memes and remixes, which also work as way for continually engaging with that reality. This vibrant and renewable engagement stands in contrast with the myth of Egyptians' political apathy that pervaded the Egyptian's collective conscience prior to the Arab Spring uprisings.

Following Egypt's widely unpopular surrender of two Egyptian Islands, Tiran and Sanafir to Saudi Arabia, many spontaneous protests erupted despite Egypt's infamous protest law. ${ }^{7}$ Figure 5, shows two of several memes created by A1 around the picture of the speaker of the Egyptian House of Representatives, Ali Abdel Al, following the surrender of the islands. The doctored pictures show the speaker holding the flag of Saudi Arabia, and another as a DJ underneath a disco ball, possibly running a party; both pictures symbolised the creator's perception of Egypt's apparent subordination to Saudi Arabia.

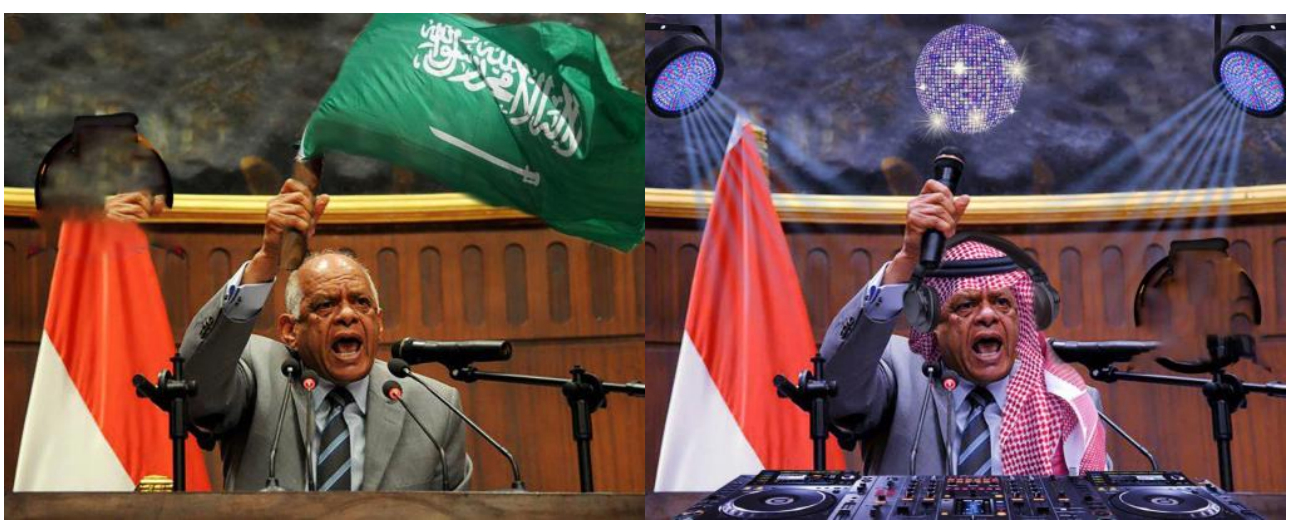

Figure 5. Speaker of the house of representatives waving the Saudi flag (Left) and wearing Saudi headdress while running a DJ (Right) (Image source: A1).

7 The new protest law required 3-day prior notification, and gave the Interior Ministry the right to cancel, postpone or change the location of the demonstration based on "serious information or evidence" regarding the security of the protest. 
Sometimes the memes and remix videos themselves are resurrections of old or forgotten movie scenes, yet ones that are dormant in the collective memory of Egyptian youths. They are given a new life, every time they are applied to a new selection of contemporary contexts and situations. By acquiring new layers of meaning with every new trend, it persists in youths' memories, however, in a different reincarnation. El-Limby, was a very popular comedy movie from 2002. In a scene of a conversation between a son, actor Mahmoud Sa'ad, and his mother, actress 'Abla Kamel, he asks her for money while she continually makes excuses for not giving him that money. This scene was reimagined by A1 as a conversation between an average Egyptian citizen (the son) and the government (the mother) (Figure 6). In the scene, the government tells the citizen that they have granted him a raise of 7 L.E. (43 cents) on the occasion of the holy month of Ramadan, the citizen asks the government to make it 10 L.E. (62 cents). But the government starts giving excuses such as the failing economy, the expenses of construction for a new branch to the Suez Canal, and the national currency depreciation, only to end with the announcement that they will be offering judges 6,500 L.E. on the occasion of the Islamic month of Sha'aban, at which point Sa'ad, in the role of El-Limby, exclaims: "So now the economy has flourished!" This meme was an apparent political allusion to the state collusion with the judiciary system in exchange for their overlooking corruption and human rights violations ("Egypt" 2018). With memes like this, youths can imagine their favourite mainstream celebrities saying and doing things that would never be allowed in mainstream media productions.

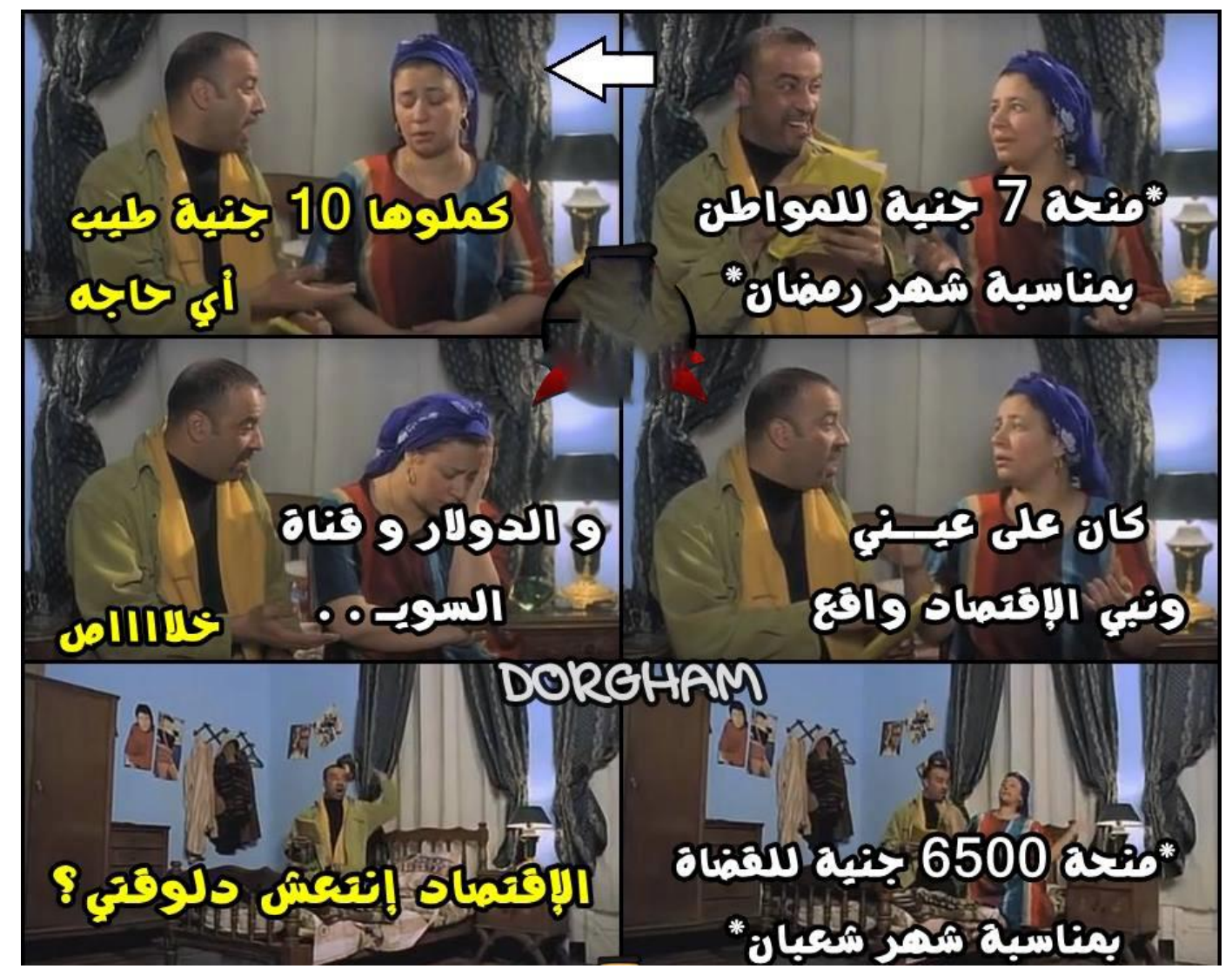

Figure 6. Scene from El-Limby reimagined as a conversation between an Egyptian citizen and the government (Image source: A1).

Bakhtin's concept of the grotesque represented the "contradictory and double-faced fullness of life" from "negation and destruction" through death to "the birth of something new and better" (Bakhtin 1984: 62). Unable, and possibly unwilling, to participate in mainstream culture, 
Egyptian youth cut and appropriate their own playful version of this mainstream culture. Remix videos or memes from movie or TV scenes represent the birth of a new meaning to the original scenes. They are the "grotesque" form of the original videos, deformed to deliver an entirely different yet playful meaning through familiar characters and setup. This served to challenge the false unity of officialdom (Bakhtin 1984), but, at the same time, to present new meanings in familiar tones and faces. Yara, a fan participant, noted that the use of old familiar scenes in remix video worked to grab her attention in ways new videos could not, especially when applied to political situations.

The continuous stream of memes/remixes around topics that change daily, turns trends into sites of renewal. Like Bakhtin's carnival, these fleeting trends are a "phenomenon in transformation, an as yet unfinished metamorphosis, of death and birth, growth and becoming" (Bakhtin 1984: 24): in the case of political trends, a fracturing in the sanctity of authority in people's minds. Yet, it is a renewal not free of self-criticism, where in coming up with jokes and tweets, youths also reflect on their temporary failures, making fun of them, but at the same time asserting their control over the social situation. Unlike modern day satire which places the satirist above the object of ridicule, people's festive laughter does not exclude them from the wholeness of the world they are laughing at.

\section{They who laugh last: developing a carnivalesque identity}

Laughter is perceived as a coping strategy especially at times of political and religious repression (Knepp 2013). Juni \& Katz (2001: 137). for example, argue that the use of self-deprecation in Jewish humour was a means of pre-emptive self-defence, where self-debasement worked to eliminate "an Achilles' heel and a manoeuvre intended to ensnare and entrap the aggressor." Hence, satire was Egyptian youths' way of making oneself invincible to outside attacks from either the older generation or the state-supporters.

Humour can work to both comfort and empower, at times serving as an escape and at others working to build a sense of temporary superiority over their oppressors (Scruton 1987). A fan participant described her motivation for following the satirical pages as an "escape from the real world and everyday problems to live in the virtual world for a while." She added: "I want to laugh. Yes, I sometimes come for news, but mostly [satire] wins." Another fan, Yara, attributed the turn to satire to the fact that it was "a sort of a release, where youths [were] trying to release their anger because they [had] no other way. So at least they created [satire]."

In response to the shrinking public space, Egyptian satirical Facebook pages adopt Rabelais' approach to creativity in posting about laughter not "tears." Arming themselves with a "just for fun" disclaimer, they create new spaces of their own. One of the administrators sarcastically asserted: "We are very trivial!" Yet in the same interview, he noted how their mission was to break taboos and encourage people to become more expressive with their voices. This sheds doubt on whether they internalise this proclamation of trivium, or just use it as a protective strategy. As Lockyer \& Pickering (2008) suggest, the "only joking" excuse makes it difficult for receptors to object to the joke if it oversteps the marks and causes offence.

Some pages such as A1 utilise a nonchalant malnourished half-shaved character as their logo. Unlike most comic characters, he displays no super-hero qualities except for his ability to make light of the hardest social or political situations. To them, this is a "super" trait in its own right: to be able to survive and, at the same time laugh, despite the stifling political, economic and social situations. Khairy, a 38-year-old male fan participant, noted that satire was what people resorted to in order to survive: "it's the gradual solution. There are two ways to change the political system: gradual or radical. There's a common agreement that a radical change would bring more harm than benefit, so it has to be gradual." 
Nonchalance was sometimes a political statement of non-approval. When students of the Egyptian high school diploma (Thanaweyya 'Amma) were asked on their history test what would have happened if the military leader had not given his speech on June $30^{\text {th }} 2013,{ }^{8}$ A1 responded with a meme, featuring a soldier (symbolising the student) riding behind a blonde on a motorcycle while praying: "Oh God forgive me for all the lies I am about to tell, but it's my future on the line" (Figure 7). The joke was premised on an assumed shared dislike of the current leadership and how it came to power, all while acknowledging youths' dilemma in having to navigate and make do within its governing system. In this context, subversions are temporal and ephemeral yet leave a long-lasting stream of collective memories that constitute the basis for a newly developing carnivalesque identity.

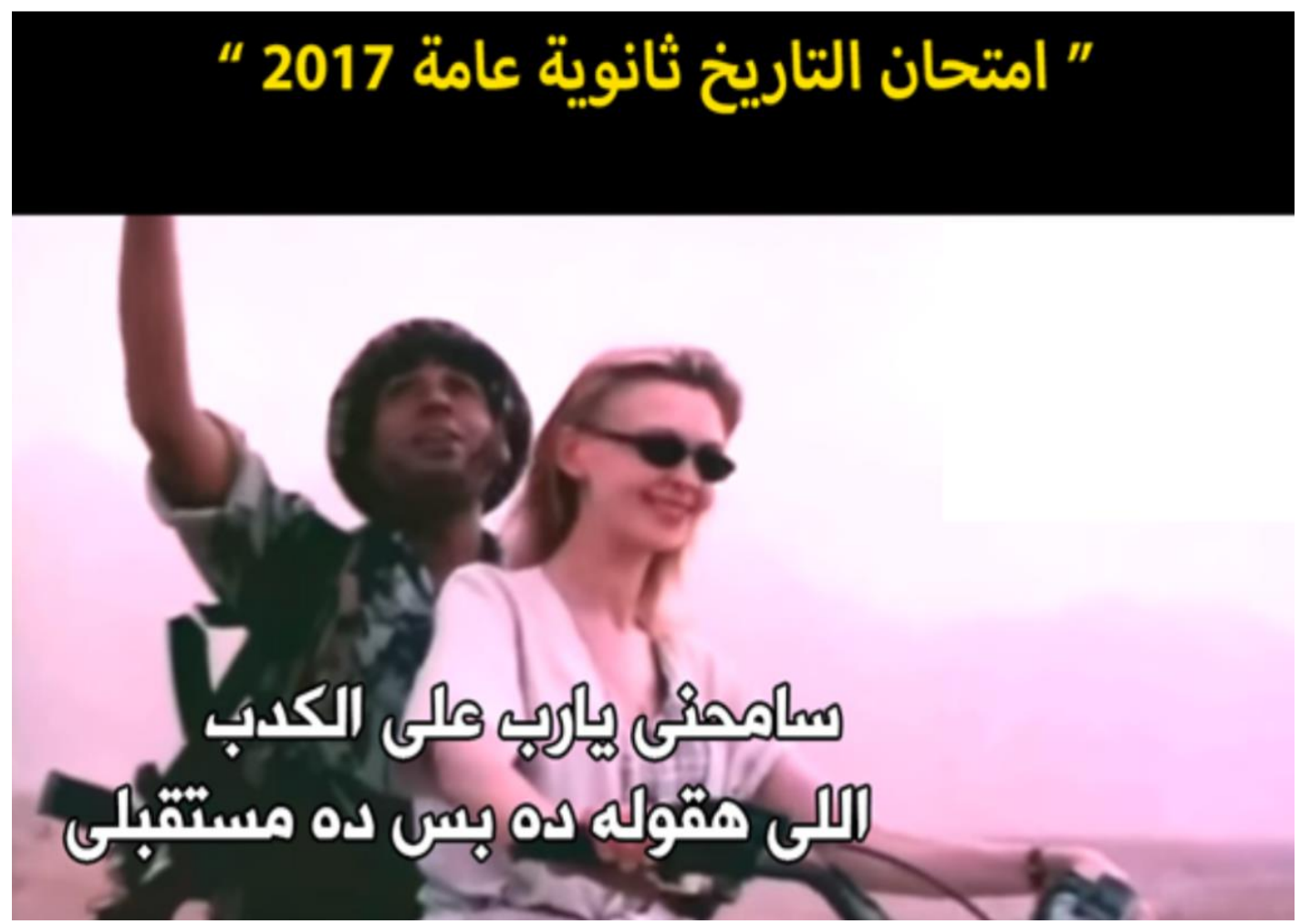

Figure 7. History Test: "What would have happened if the military leader had not given his speech on June $30^{\text {th }} 2013$ ?" Soldier on a bike: "Oh God forgive me for all the lies I am about to tell, but it's my future on the line" (Image source: A1)

Humour is also the way creative administrators use to keep their young audience engaged and connected. While this may reflect their desire to increase their number of followers, it is also a reflection of the value of shared laughter. Levine (1978: 359) noted the social dimension of humour where humour can work to create "a sense of group cohesion" by "widening the gap between those within and those outside the circle of laughter." The memes and videos circulated are not necessarily of very high quality; at many times, pictures are crudely photoshopped in memes, or the audio does not synchronise with the moving picture in the video. Many meme/remix creations are produced by the fans themselves and not only by the semiprofessional page administrators who are more experienced. These creative works, however, are not circulated for their quality as much as they are circulated for the value of the shared joke and indignation expressed through satire. Additionally, the embedding of criticism in the stream Morsi.

${ }^{8}$ June $30^{\text {th }}, 2013$ marked the military-backed popular protests, which led to the overthrow of Mohammed 
of other real-life non-political events, such as the memes about the rising summer heat or the stress of exams, serves to ground much of these pages' contents in the everyday lives of their followers. Hence, whenever political criticism is passed on these pages, it comes from administrators who are like them and who experience the same daily challenges they face. By sharing laughter, and the common understanding of a joke, youths are indirectly creating a community that is less scrutinised by authorities, while maintaining an open connection with that community.

\section{Conclusion}

Bakhtin's carnival was the lens through which he understood the humour of Rabelais, and it was the folk context that gave Rabelais's humour a political dimension. Guided by Bakhtin's concept of the carnivalesque, this study examined how the satirical Facebook pages of Egyptian youth serve both political and cultural roles in challenging the state and its cultural apparatuses all while offering youths a space for entertainment and playful experimentation missing from the official, highly scrutinised, public space. With the gradual shrinking of that space, satirical Facebook pages became youths' way of congregating and expressing themselves. The use of humour allows them to do so without raising alarms or stressing their already polarised social relations. While at times the memes and remixes work to release the pressures of authoritarianism, often times, they work to break down the sanctity of the official political and/or cultural figures. Shared subversions build awareness through satire, all while providing youths with a sense of control and community.

Despite their somewhat low quality, which also attests to their grass-rootedness, memes are shared for the value of their collective laughter. Like Bakhtin's carnival, the more homely, crude, profane and grotesque, the truer to one's origins and more powerful (in a mythical sense) these pages become. In other words, the same ingredients of power that grant mainstream media a more influential position work to delegitimise its products in the eyes of resisting youths. Because of their subversiveness and communal nature, crudely created memes are considered superior in comedy to the professional scenes they are built upon.

Satirical Facebook pages act as a second life where youth are still allowed to interact, participate and engage in playful experimentation. Hence, these pages work to formulate a new folk culture distinguished by a carnivalesque identity that is both subversive and playful. This new culture, however, does not deny its roots in official culture, where past productions are revived and infused with new pertinent meanings through constant engagement with reality. Because of their highly contextual nature, their ephemerality and the volume in which they are produced, understanding the true intention behind the creative memes and remixes requires audience to be close followers of the pages' content. Knowledge of the history of some of these memes is important in understanding the multi-layered meanings they acquire over time. Past productions thus act as a common ground and special language for interaction among youths, and ultimately, a launching pad for their creative subversion.

By reimagining the ladder of authority (reversal) and taking control over the newly assigned meaning of popular culture scenes or by reading of current events (renewal), Egyptian youths managed to sustain their conversation that started with the Arab spring uprisings, however, in creative modalities. The carnival mechanisms of reversal and renewal therefore constitute the waves of an aspiring cultural movement that works to slowly erode the structures of official authority. Like the carnival, these youths are part of the wholeness of the world they are making fun of, transforming it while being transformed in the process. 


\section{References}

Abdulla, R. (2014). 'Egypt's media in the midst of revolution'. Carnegie Endowment for International Peace. Retrieved May 25, 2019 from https://carnegieendowment.org/2014/07/16/egypt-s-media-in-midst-of-revolution-pub$\underline{56164}$

Astapova, A. (2017). 'Rumour, humour, and other forms of election folklore in non-democratic societies: The case of Belarus'. Folklore: Electronic Journal of Folklore, 69, pp. 15-48.

Astapova, A. (2015). 'Why all dictators have moustaches: Political jokes in contemporary Belarus'. Humour: International Journal of Humour Research 28 (1), pp. 71-91.

Bahaa Al Deen, A. (1990). Ayam Laha Tareekh [Days that Have History]. Cairo, Egypt: Dar Al Helal.

Bakhtin, M. M. (1984). Rabelais and his World. Bloomington, IN: Indiana University Press.

Bauer, M. W. \& Gaskell, G. (eds.). (2000). Qualitative Researching with Text, Image and Sound: A Practical Handbook for Social Research. Thousand Oaks: Sage.

Braun, V., \& Clarke, V. (2006). 'Using thematic analysis in psychology'. Qualitative Research in Psychology 3 (2), pp. 77-101.

Cao, X., \& Brewer, P. R. (2008). 'Political comedy shows and public participation in politics'. International Journal of Public Opinion Research 20 (1), pp. 90-99.

Davies, C. (2002). The Mirth of Nations. Piscataway: Transaction Publishers.

'Egypt: Events of 2018'. (2018). Human Rights Watch. Retrieved November 12, 2019 from https://www.hrw.org/world-report/2019/country-chapters/egypt

'Egypt is suffering from a crisis in morality [Masr toa'ny Azmet Akhlak]'. (2013). Mobtdaa. Retrieved November $14^{\text {th }}, 2019$ from https://www.mobtada.com/details/104034.

'Egyptian satirical group arrested over insulting video'. BBC News. Retrieved October 30, 2021 from https://www.bbc.com/news/world-middle-east-36256451

Elliot, S. (1999). 'Carnival and dialogue in Bakhtin's poetics of folklore'. Folklore Forum 30 (1/2), pp. 129-139.

El-Menawy, A. (2017). 'Egyptians' sense of humour is very telling'. Arab News. Retrieved May 26, 2019 from http://www.arabnews.com/node/1165171

Elsayed, Y. (2016). 'Laughing through change: Subversive humour in online videos of Arab youth'. International Journal of Communication 10, pp. 5102-5122.

'Fastest-growing pages in Egypt'. (2019). Social Bakers. Retrieved November 6, 2019 from https://www.socialbakers.com/statistics/facebook/pages/total/egypt

Freud, S. (1963). 'Jokes and their relation to the unconscious.' In Standard Edition of the Complete Psychological Works of Sigmund Freud, Vol. 5. New York: Norton. (Original work published 1905).

Frey, L., Botan, C. \& Kreps, G. (1999). Investigating Communication: An Introduction to Research Methods (2nd ed.). Boston: Allyn and Bacon.

Grundlingh, L. (2018). 'Memes as speech acts'. Social Semiotics 28 (2), pp. 147-168.

Gupta, P. (2014). 'Bassem Youssef's weekly satirical show in Egypt has been cancelled'. June, 3. Salon. Retrieved May 26, 2019 from https://www.salon.com/2014/06/02/bassem_youssefs_weekly_satirical_show_in_egypt_h as been canceled/

Helmy, M. M. \& Frerichs, S. (2013). 'Stripping the boss: The powerful role of humour in the Egyptian Revolution 2011'. Integrative Psychological and Behavioral Science 47 (4), pp. 450-481.

Houlihan, P. F. (2001). Wit and Humour in Ancient Egypt. Ontario: Rubicon Press.

Jackson, P. (1991). 'The cultural politics of masculinity: Towards a social geography'. Transactions of the Institute of British Geographers 16 (2), pp. 199-213. 
Jenkins, H. (2010). 'DIY video 2010: Political remix (Part One)'. Confessions of an Aca-fan. $\begin{array}{llll}\text { Retrieved May } & 2019 & \text { 26, } & \end{array}$ http://henryjenkins.org/blog/2010/11/political_remix_video_can_empo.html

Juni, S. \& Katz, B. (2001). 'Self-effacing wit as a response to oppression: Dynamics in ethnic humour'. The Journal of General Psychology 128 (2), pp. 119-142.

Kandeel, M. (2016). 'A conversation with my brother, atheist with Mohammed Sobhy'. Mada Masr. Retrieved May 26, 2019 from https://goo.gl/inXepT

Khalaf, R. (2012). 'So who are we?'. Al Ahram Weekly. Retrieved May 26, 2019 from http://weekly.ahram.org.eg/Archive/2011/1042/cu3.htm

Knepp, R. (2013). Laughing Together: Comedic Theatre as a Mechanism of Survival during the Holocaust. Masters' Thesis. Retrieved May 26, 2019 from https://scholarscompass.vcu.edu/cgi/viewcontent.cgi?article $=4039 \&$ context $=$ etd

Laineste, L. \& Voolaid, P. (2016). 'Laughing across borders: Intertextuality of internet memes'. The European Journal of Humour Research 4 (4).

Levine, L. W. (1978). Black Culture and Black Consciousness: Afro-American Folk Thought from Slavery to Freedom. Oxford: Oxford University Press.

Lockyer, S. \& Pickering, M. (2008). 'You must be joking: The sociological critique of humour and comic media'. Sociology Compass 2 (3), pp. 808-820.

Morreall, J. (2014). 'Humour, philosophy and education.' Educational Philosophy and Theory 46 (2), pp. 120-13.

'President smiley face'. (2016). BBC News. Retrieved May 26, 2019 from https://www.bbc.com/news/blogs-trending-35375790

'Protest and Freedom of Assembly in Egypt'. (2017). October 18. The Tahrir Institute for Middle East Policy. Retrieved May 26, 2019 from https://timep.org/reportsbriefings/protest-and-freedom-of-assembly-in-egypt/

Radwan, H. (2017). 'Joking and reproach'. April 7. Sasa Post. Retrieved January 1, 2021 from https://www.sasapost.com/opinion/sarcastic-crying/

Saldana, J. (2009). The Coding Manual for Qualitative Researchers. Thousand Oaks: SAGE Publications.

Attardo, A. \& Ergül, H. (2014). ‘Ancient Egypt, humor in'. In S. Attardo (ed.), Encyclopedia of Humor Studies (pp. 30-32). Thousand Oaks: Sage Publications.

Scruton, R. (1987). 'Laughter'. In J. Morreall (ed.), The Philosophy of Laughter and Humour (pp. 156-171). Albany: SUNY Press.

Shifman, L. (2014). Memes in Digital Culture. Cambridge: MIT Press.

Singh, R. K. (2012). 'Humour, irony and satire in literature'. International Journal of English and Literature 3 (4), 63-72.

'Social media users in Egypt: Facebook insights and usage in Egypt, 2018'. (2018). Digital Marketing Community. Retrieved May 25, 2019 from https://www.digitalmarketingcommunity.com/indicators/facebook-insights-usage-inegypt-2018/

'Social media stats in Egypt'. (2019). Stat Counter Global Stats. Retrieved November $6^{\text {th }}$ from https://gs.statcounter.com/social-media-stats/all/egypt

Stark, C. (2003). "What, me worry?": Teaching media literacy through Satire and Mad Magazine'. The Clearing House 76 (6), pp. 305-309.

Twenge, J. M., Martin, G. N. \& Spitzberg, B. H. (2019). 'Trends in US adolescents' media use, 1976-2016: The rise of digital media, the decline of TV, and the (near) demise of print.' Psychology of Popular Media Culture 8 (4), 329.

van de Bildt, J. (2015). 'The quest for legitimacy in postrevolutionary Egypt: Propaganda and controlling narratives'. The Journal of the Middle East and Africa 6 (3-4), pp. 253-274. 
Walsh, D. (2019). 'Egypt's soap opera clampdown extends el-Sisi's iron grip to TV'. The New York Times. Retrieved November 7, 2019 from https://www.nytimes.com/2019/04/03/world/middleeast/sisi-egypt-soap-opera.html

Woodsome, K., Elshinnawi, M. (2012). 'In uncertain times, Egyptian comedy thrives'. Voices of America. Retrieved November 7, 2019 from https://www.voanews.com/middleeast/uncertain-times-egyptian-comedy-thrives

Zidani, S. (2016). 'Arab Internet humour: From Adele to Adeela'. Medium. Retrieved November 14 from https://medium.com/@Sulafa/arab-internet-humor-from-adele-to$\underline{\text { adeela-b8cc2fe2db9a }}$ 